\title{
It's not late entry: human capital, welfare states and the pension penalty experienced by post-war migrants who retired in the European Economic Area
}

\author{
Paul Bridgen ${ }^{1 *}$ (D), Traute Meyer ${ }^{1}$ (D) and Lisa Davison ${ }^{1,2}$ (D) \\ ${ }^{1}$ ESRC Centre for Population Change, University of Southampton, Southampton, UK and ${ }^{2}$ Faculty of Social \\ Sciences, University of Stirling, Stirling, UK \\ ${ }^{*}$ Corresponding author. Email: Paul.Bridgen@soton.ac.uk
}

(Accepted 8 November 2021)

\begin{abstract}
Since the 2000s, migration within and into the European Economic Area (EEA) has increased significantly. Some migrants will retire in their destination countries. This makes questions about their retirement protection increasingly relevant for social policy. To address this, we examine past experience. Using the Survey of Health, Ageing and Retirement in Europe (SHARE), we compared the pensions of post-1945 migrants, who settled in their host country, with non-migrants. We considered migrants who moved into and within the EEA, from poorer and richer countries. Where pensions were lower we sought to explain this in relation to the migration literature. As expected, we found some evidence that migrants' pensions were lower, although significant variations were observed between EEA migrants and non-EEA migrants. However, surprisingly there were few indications that migrant pensions were lower because migrants as a whole were disadvantaged through late labour market entry or employment discrimination. Instead educational disadvantage mattered most, particularly for the highly educated: all highly educated migrants received lower rewards for their human capital than comparable non-migrants. Migrants who settled in countries with less-protective pension systems were also disadvantaged. Making retirement outcomes for migrants more equal would, thus, mean improving career opportunities for highly educated migrants and steps towards more-inclusive pension systems everywhere.
\end{abstract}

Keywords: immigration; pensions and retirement; welfare systems; Survey of Health; Ageing and Retirement in Europe (SHARE) dataset; first-wave Europea Union migration; migrant pensions; non-migrant pensions; labour market integration

\section{Introduction}

Increased migration within and into the European Economic Area (EEA) during the last decade has focused academic and political attention on migrants' social 
rights. This has mainly addressed immediate social policy challenges (Green et al., 2008), not future effects built over migrants' lifecourse. Economists generally assume migrants will return home to retire, taking advantage of the greater purchasing power of their host country pensions in their country of origin (Stark, 1991; Dustmann, 1996; Dustmann and Kirchkamp, 2000; Poulain and Perrin, 2002; de Coulon and Wolff, 2005; Klinthäll, 2006). In contrast, evidence from the first post-war wave of mainly economic migration within and to Europe suggests some migrants stayed, having integrated economically and socially (Castles et al., 1984; Edin et al., 2000; de Coulon and Wolff, 2005). Research has not included refugees, who seem unlikely to return at any stage of the lifecourse because they fear persecution. In 2020, 8.3 million foreign-born individuals aged 65+ were living in the European Union (EU15), Norway and Switzerland, many of whom would have migrated much earlier in their lifecourse (Eurostat, 2021, our calculations; see Appendix 1 in the online supplementary material).

It is important to know - for policy making and reasons of social justice - how migration affects the lifecourse and whether migrants who stay after retiring will have similar incomes to comparable non-migrants. Theoretically, there are good reasons to believe they will not. The empirical evidence, however, is inconclusive and existing studies make no attempt to establish the most important factors affecting migrants' pensions (details below). This paper contributes to filling this gap, by assessing in more detail than hitherto how country of birth affects the public pension income of migrants who retire in EEA countries and which are the major determinants of this process. It is based on a large sample from the Survey of Health, Ageing and Retirement in Europe (SHARE) (details below). We compare EEA and non-EEA migrant groups with non-migrants, EEA with non-EEA migrants, and we also compare four migrant sub-groups with each other: intra-EEA ${ }^{1}$ migrants from Northern and Southern countries; migrants into the EEA from countries with higher and lower levels of Gross Domestic Product (GDP) per capita. These individuals came during labour shortages in several European countries after 1945, peaking in the 1960s. Initially many were from ex-colonies, increasingly they also came from European countries outside the trade bloc, some for humanitarian reasons (Bridgen and Meyer, 2020).

Based on linear regression analyses, this paper confirms migrants are at higher risk of low public pensions than non-migrants when they retire, but surprisingly there is little evidence to suggest this is because they enter the labour market late or experience labour market segmentation. Instead, it is because their returns on human capital are lower than non-migrants' and their risks are greater in countries with weaker pension systems. The next section summarises the literature about the factors affecting migrants' host country incomes on retirement. We then outline our methods, present descriptive statistics and regression results, and discuss the findings.

\section{Retirement incomes of migrants who stay}

Economic theories of migration (Stark, 1991; Dustmann, 1996; Dustmann and Kirchkamp, 2000) expect migrants to integrate fully in host country labour markets to maximise income, including investment in human capital. This should lead to a 
decline of initial wage disparities between non-migrants and similarly skilled migrants, albeit they do not disappear entirely (Constant and Massey, 2005). As a consequence, if migrants retire in their host country, their pension rights should be similar to non-migrant workers. ${ }^{2}$

In contrast, dual or segmented labour market theory suggests most migrants will enter the labour market's periphery and find escape difficult (Castles and Kosack, 1973; Piore, 1979). Employment discrimination based on xenophobia will exacerbate the wage gaps to non-migrant core workers (Becker, 1957). Chances of progressing vary by skill, country of origin (Chiswick, 1979) and whether they are economic migrants or refugees (Cortes, 2004). Those whose human capital aligns with host country labour markets will do best (Dustmann and Fabbri, 2003; Lancee and Bol, 2017). Continuing disadvantages prolong the wage gap, leading to pension inequality.

Research on the EU (Zwysen, 2019), the United States of America (USA) (Powers and Seltzer, 1998; Cortes, 2004; Hall and Farkas, 2008), Germany (Constant and Massey, 2005; Mika and Tucci, 2006), Spain (Comet, 2014) and Switzerland (Bolzman, 2012) supports this theory, showing migrants overrepresented at the periphery, low-paid and less mobile. For example, migrants to Germany only improved their situation slowly, based on skills acquired in the host country (Constant and Massey, 2005). Success also depends on country of origin and status. For example, language skills protected Eastern European migrants to Spain better against unemployment during the 2009/10 recession than African and Latin American migrants (Cebolla-Boado et al., 2015). Refugees to the USA, United Kingdom (UK) and EU countries did worse in labour markets initially but caught up over the longer term (Cortes, 2004; Ruiz and Vargas-Silva, 2017; Zwysen, 2019).

However well, or badly, migrants perform in their host country labour market, the overall impact this will have on migrants' pension will be affected by who stays after retirement - will it mainly be the richest or poorest? Economists expect most migrants to return on retirement and are split on whether the few who remain are likely to be the richest or poorest (Stark, 1991; Taylor, 1999). Empirical studies are inconclusive. Among older migrants to Sweden between 1979 and 1996, returners' previous average incomes were higher than remainers' (Klinthäll, 2006: 170). A Swiss study demonstrated the opposite, showing that, for the decision to stay or go, family ties are important too (Bolzman et al., 2004).

Welfare states, particularly social insurance, will also play a role for pension outcomes. Analysis shows that migrants have been disadvantaged by national legislation made for the pensions of immobile populations (Warnes, 2006), with entitlements based on workplace contributions (some public, all occupational) or residency (only public schemes). Migrants who enter host countries later in working life will have lower entitlements but the exact impact will depend on whether systems are earnings-related (e.g. Germany, France), residence-based (i.e. more redistributive) but based on long membership (e.g. Denmark, Netherlands), and on how generous they are (Möhring, 2015; Heisig et al., 2018; Bridgen and Meyer, 2019). Intra-EEA migrants have the right to aggregate contributions to different countries' state-run earnings-related schemes (Ackers and Dwyer, 2004; Meyer et al., 2012). Non-EEA migrants must rely on bilateral agreements. 
What impact does such institutional diversity have for migrants' pensions? Research so far agrees about migrants' retirement disadvantage, compared to nonmigrants, and that pension institutions have an effect, but there is no agreement about its direction and magnitude. Country case studies show a gap between migrants' and non-migrants' pensions (for Germany: Mika and Tucci, 2006; Hochfellner and Burkert, 2013; for the UK: Vlachantoni et al., 2017). In comparative studies, micro-simulations of current intra-EU migrants' entitlements suggest their pensions are significantly below non-migrants' and that most will be disadvantaged by institutional and, possibly more significantly, by the large wage differences between country of origin and host country (Meyer et al., 2012; Bridgen and Meyer, 2019). Regressions using the first wave of SHARE found pensions of EEA and non-EEA migrants in the EU to be lower than non-migrants' (Bridgen and Meyer, 2020), but no attention was given to the impact of different EU pension systems. An analysis of Luxembourg Income Study (LIS) data also found migrants' pensions below non-migrants', regardless of welfare regime, with Germany an exception (Morissens and Sainsbury, 2005: 651). Heisig et al. (2018) investigated the role of pension system design for non-EU retired migrants living in the EU, compared to non-migrant retirees, using the European Union Statistics on Income and Living Conditions (EU-SILC) from 2004 to 2013. They confirmed migrant disadvantage but suggest it is less distinct in countries with more redistributive pension systems. However, their approach is largely aggregated, using mainly country-level variables, therefore their data represent the averages of each country, rather than individual-level data.

\section{Research gap}

In summary, evidence is strongest that migrants enter peripheral parts of the labour market and do not escape fully, suggesting that in our sample they will have had lower lifetime wages, and thus pensions, than non-migrants. However, the literature is inconclusive about which types of migrants stay or return, whether the wealthier or less wealthy retire in their host countries, affecting outcomes differently. Moreover, little is known about the impact of wealth of the country of origin and the impact of human capital, and consideration of the impact of host country pension systems is at an early stage.

Existing studies comparing the finances of retired migrants and non-migrants suggest migrants' pensions are significantly lower, but only Heisig et al. (2018) explored systematically the reasons and they only focus on welfare states. Our study thus seeks not only to confirm the presence and quantify any migrant income gap, but also to explain it. It focuses more than previous studies on migrants' countries of origin as an explanatory variable, rather than emphasising host country differences. It does this by controlling for the fixed effects of the host countries within the study, as opposed to applying a multilevel model. A fixed-effects model still accounts for important variation between host countries, but these differences are not at the forefront, therefore, greater prominence can be placed on interpreting the impact of migrants' countries of origin on public pension outcomes. In considering the impact of welfare states, the paper focuses on public pensions, using a variable capturing the pension institutions that our sample experienced (see below). 
Based on the discussion of current literature above, we hypothesised migrants' public pensions to be substantially lower than non-migrants', because migrants enter their host country labour market late, and are likely to be at the periphery and disadvantaged when they do. However, we expect relative advantages for the EEA group because their human capital is recognised better and extended more easily in host country labour markets, and fewer are likely to be refugees. Migrants from all richer countries should also show an advantage (Bridgen and Meyer, 2019).

\section{Data and methods}

To test these hypotheses, we use the data from SHARE Waves 1-7 collected between 2004 and 2017 (Börsch-Supan, 2020a, 2020b, 2020c, 2020d, 2020e, $2020 f, 2020 \mathrm{~g}$ ), and data from the generated Job Episodes Panel based on Wave 3 (SHARELIFE; Brugiavini et al., 2020), which collected primarily retrospective data, and Wave 7. SHARE is a cross-national panel including questions on employment, retirement and pensions; it relies on a probability sample of the over 50 -year-old, non-institutionalised population. By the seventh wave of SHARE, all EU member states plus Switzerland and Israel had been included in the survey, representing almost 140,000 total respondents over the waves (Bergmann et al., 2019).

In comparison to other available European datasets used to analyse pensions, such as EU-SILC or LIS, SHARE offers more detailed migrant data. In EU-SILC, differentiation by country of origin is not attainable for non-EU migrants, nor are data on age at migration prior to 2010 (Heisig et al., 2018). In LIS, data on migration and country of birth are missing for several waves in many of the European countries (authors' own analysis from LIS, 2019). For these reasons it would not be possible using these datasets to investigate the differences between EEA and non-EEA migrants and those from richer and poorer countries.

A country fixed-effects approach was adopted in this paper as an alternative to the conventional multilevel model (Möhring, 2018). This alternative approach is more suited to data without a random sample at the upper level, a small number of countries and when the objective is to control for, rather than explain, countrylevel variation (Dingemans and Möhring, 2019). Evidence from Möhring (2012, 2015) highlights the lack of random sample in datasets such as SHARE, and identifies that country-level dummies reduce omitted variable bias, which occur in a multilevel approach due to the inability to control for all relevant country-level variables. The country fixed-effects approach demonstrates comparable results with the multilevel approach and is appropriate for analysing both individual-level variables and cross-level interactions (Möhring, 2012, 2018).

The present analysis combines the SHARE data detailed above to construct a sample from 12 European countries: Austria, Belgium, Denmark, France, Germany, Greece, Luxembourg, Netherlands, Portugal, Spain, Sweden and Switzerland. ${ }^{3}$ Other countries were excluded because of small migrant samples, lack of pension data or they were countries without EEA links. We included only retired individuals aged 60 years or $\operatorname{older}^{4}$ (28,377 persons). 


\section{Defining the migrant sample}

Six per cent $(N=1,590)$ of the aforementioned respondents were migrants because their country of birth differed from country of residence, and they were aged 18-64 on migration. Only those who migrated at working age were included because we were interested in the impact of late entry into host country labour markets. ${ }^{5}$ The remaining 26,767 respondents were categorised as non-migrants and reflected individuals living in the host countries from birth.

The migrant sample was divided by country of origin: EEA countries including Switzerland and non-EEA countries. These were divided further, by wealth: North EEA, South EEA, low GDP non-EEA and high GDP non-EEA (for further discussion, see the Descriptive statistics section). These divisions were based on related research, which found migrants' pensions affected by wealth of country of origin, particularly wage levels compared to the host country, by host country welfare institutions and by their interaction (Meyer et al., 2012; Bridgen and Meyer, 2019). Divisions were also consistent with expectation of underperformance evident in the literature on labour market segmentation; and allowed us to explore the impact of human capital developed in migrants' country of origin.

Data from the Job Episodes Panel were used to identify migrants who had migrated on more than one occasion by examining country of residence by each year of reported data. Preliminary analysis from the Job Episodes Panel (not reported within this paper) suggested 26 per cent of migrants migrated between three or more countries, and 7 per cent migrated between two countries at least twice; both of these scenarios were categorised as 'multiple migrants'. Within the final sample, multiple migrants represented 16 per cent $(\mathrm{N}=259)$ of the overall migrant sample.

Host country was based on the country of residence when completing SHARE interviews. This applied to both single and multiple migrants, i.e. in cases where migrants had resided in three or more countries, country of residence represented the current country of residence, with all previous countries, other than country of origin, excluded from the analysis.

\section{Public pension}

To assess retirement income, our dependent variable was participants' public pension entitlement, based on self-reported average payment of public pension within the last year: 'After taxes, about how large was a typical payment of your public old age pension' (SHARE, 2017: 241). Reported pension payments covered different time periods (e.g. weekly, monthly) which we converted into annual payments. ${ }^{6}$ Because our sample included participants from all seven waves (2004-2017) we had to standardise by inflation; using 2015 baseline inflation rates for each host country (measured by Consumer Price Index; Organisation for Economic Co-operation and Development (OECD), 2018). We multiplied respondents' reported pension values by the corresponding rate for their interview wave.

When conducting the regression analyses, a logarithmic transformation of the pension variable was used; the log-linear model is an appropriate method to counteract positively skewed data (Benoit, 2011); Field, 2013). In the results tables, the interpretation of the log-transformed dependent variable is displayed as pension 
difference, as a percentage, and was calculated using the exponential of the coefficient through the formula: $(\operatorname{Exp}(B)-1) \times 100$.

To control for pension scheme generosity within host countries, we computed a variable using replacement rates for minimum and standard pensions from the Comparative Welfare Entitlement (CWED) (Scruggs et al., 2017a, 2017b) and Social Insurance Entitlement (SIED) (Korpi and Palme, 2008) datasets. The aim was to control in regressions for the generosity of host country pension systems, allowing for the particular entitlement issues migrants might confront, e.g. shorter periods of accrual in the main public pension system after entry into the host country. The CWED and SIED datasets were used because their replacement rate data are based on the pension system that workers in our sample would have actually experienced during their working life. This makes our pension generosity variable more precise than simple divisions between Bismarckian and Beveridgean countries or welfare state types (Meyer, 2017; Ebbinghaus, 2021), and more precise than the pension redistribution index applied by Heisig et al. (2018). The latter, which is based on OECD data from the 'Pensions at a Glance' series (OECD, 2005-2019), has accepted limitations with respect to mismatched cohorts between the data sources. This is because the data are based on projections of the impact of current pension systems (i.e. beginning in 2002) on the replacement rates of hypothetical workers who live their whole working life under that system (OECD, 2005-2019: 39 ); it does not thus relate to the performance of the pension systems that current pensioners will have experienced. Indeed, many of our sample would have retired by the time the pension systems covered by the OECD were in place. In contrast, the CWED provides the projected replacement rates for an average waged worker retiring in any given year since 1970 . The SIED provides such rates for equivalent individuals retiring every five years from 1950. In both cases, they also provide information about replacement rates from the minimum pension received by workers who would not have developed an entitlement to the main public pension.

Using these datasets, for each country for which there were data, ${ }^{7}$ we collected the CWED replacement rates for minimum pensions and standard pensions for the years 1970-2015 and the SIED replacement rates for every five years since 1960. Our decision to include minimum and standard pensions was based on the labour market and welfare state entitlement literature reviewed in the paper. This shows that labour market and welfare state entitlement conditions might prevent migrants from initially building up entitlement to the main pension; access was likely to improve the longer the migrant stayed in the host country. Based on these data, we generated a ranking for the destination countries for each dataset, combined both and divided the countries into less- and more-protective groups (see Appendix 2 in the online supplementary material).

Due to the country fixed-effects approach, the use of country dummy variables explains all upper-level variance (Möhring, 2012); therefore the main effects of pension generosity (country level) could not be included. In the analyses, an interaction between migration status and pension scheme generosity was included to account for the cross-level impact of migrating into a country with a more protective pension scheme. The use of cross-level interaction effects is a suitable alternative and has previously been demonstrated with SHARE data (Hyde and Dingemans, 2017). 


\section{Analyses}

In linear regression models we first compared, in our combined sample, non-migrants with all migrants. To control for the differences between host countries, the initial model (Model 1) included only the country dummy variables and migration status. In the second model, we divided individuals by low, medium or high levels of education, expecting greater vulnerability for the less educated. We also controlled for sociodemographic and socio-economic factors including age, sex, marital status and household income. We expected greater vulnerability among retired older women (Ginn, 2003). The household income variable includes income from employment, pensions, benefits and assets, and was included as a control for socio-economic status. We adjusted household income for inflation using the same data as for the dependent variable, and divided it into quartiles. As household income included pension payments, we ruled out collinearity with the dependent variable. In all circumstances, the variance inflation factor and tolerance were well within accepted parameters. Furthermore, bivariate analysis indicated a weak correlation between the dependent variable and household income $\left(r_{\mathrm{s}}=0.393, p<0.001\right)$.

In the fully adjusted model (Model 3 ), we controlled for the country-level interaction variable accounting for the impact of being a migrant in a country with a more-protective pension scheme. Additionally, to determine the combined effect of having a high-level education and being a migrant we also included an interaction term between high education and migrant status. ${ }^{8}$ Previous work suggested migrants tended to fair better in more redistributive host country pension systems and that host country labour markets recognised the education of non-European migrants less than European migrants and non-migrants (Cebolla-Boado et al., 2015; Bridgen and Meyer, 2020). For ease of interpretation and in line with recommendations in the methodological literature (Hayes, 2017: 244), we include interaction plots in the Results section to highlight the impact of these interaction terms. ${ }^{9}$ We also considered the inclusion of an interaction term between household income and migrant status. This, we believed, might indicate differences between migrants and non-migrants in the translation of household income into a pension, but on testing in our regressions this proved non-significant and/or invalidated the model. We hypothesised that significant differences observed between migrants and non-migrants in the fully adjusted model, after the inclusion of all controls, would likely be the product of unmeasured factors for which we could not directly control, such as late labour market entry and labour market segmentation.

To determine the extent to which country of origin mattered for migrants' pensions, we ran additional regression analyses using the same models to compare EEA and non-EEA migrants with non-migrants (second and third analyses). We also examined differences between the migrant groups only: the fourth regression compared EEA with non-EEA migrants, and the fifth regression divided migrants by North/South EEA and low/high GDP non-EEA to investigate potential disadvantages between richer and poorer countries. In these migrant-only analyses, we used the same control variables (age at interview, sex, marital status and household income) as in the first three analyses, but also controlled for additional migrantspecific pension-relevant factors: migrants who moved more than once, age on migration, decade of migration and acquisition of citizenship. In these regressions, interactions were included only between EEA migration and education to 
determine whether EEA migrants experienced a human capital advantage over non-EEA migrants. The pension generosity interaction was excluded because in the migrant-only analyses (fourth and fifth regressions) it introduced collinearity between the interaction and the predictor and moderator variables, elevating variance inflation factors and overestimating standard errors (Field, 2013). This compromised our ability to determine the importance of predictors accurately.

\section{Descriptive statistics}

Our sample includes 26,767 non-migrants, 958 EEA migrants and 632 non-EEA migrants (Tables 1 and 2). Among both non-EEA and the South EEA groups, men were slightly overrepresented; women were overrepresented only among North EEA migrants. Most interviewees were 60-69 years old. The share of non-EEA migrants in the youngest and oldest groups was slightly higher than of EEA ones; they were also slightly older when they migrated. The marital status of groups was similar, though marriage was less likely and divorce and separation more prevalent among non-EEA migrants. The migrant groups were better educated than non-migrants: 56 per cent achieved medium or high education compared with 52 per cent of non-migrants; most markedly, 68 per cent of North EEA migrants had medium or higher education, whereas South EEA countries had the highest share of the lowest educated (72\%).

North EEA migrants were from Austria, Belgium, Denmark, Finland, France, Germany (largest proportion, $\mathrm{N}=249$ ), Liechtenstein, Luxembourg, Netherlands, Norway, Sweden, Switzerland and UK. South EEA migrants were from Cyprus, Greece, Ireland, Italy (largest proportion, $\mathrm{N}=174$ ), Portugal and Spain. Ireland, despite being located in Northern Europe, was grouped with Southern EEA countries due to lower GDP during the period of migration, which aligned more with the Southern than Northern EEA countries. The third and fourth groups came from outside the EEA, separated by poorer and richer countries (see below). ${ }^{10}$ Of the 40 countries of origin of the higher GDP non-EEA group, 18 are European and most were statesocialist before the Eastern bloc's collapse in 1989 (234 migrants). Of the 22 others, four are African, 11 are Asian, four are South American and three are North American (202 migrants). Of the 39 countries of origin of the poorer non-EEA group, eight are European (75 migrants), 15 are African, nine are Asian, four are South American and three are North American (121 migrants). Most EEA migrants settled in Switzerland (19\%) and Luxembourg (19\%); most non-EEA migrants settled in Germany (26\%) and France (22\%). Among the migrants, all migrated between 1945 and 2010, the largest percentage (33\%) between 1960 and 1969. Across all migrant sub-groups, the 1960s was the modal decade for migration.

\section{Results}

\section{Migrants versus non-migrants}

The initial analysis, adjusted only for country fixed effects, suggested migrants' pensions were significantly lower than non-migrants' pensions, by 11 per cent (Table 3). After accounting for level of education and controlling for sociodemographic and socio-economic factors in Model 2, they were, on average, 
Table 1. Descriptive statistics for migrants and non-migrants

\begin{tabular}{|c|c|c|}
\hline & Non-migrants & Migrants \\
\hline $\mathrm{N}$ & 26,767 & 1,590 \\
\hline & \multicolumn{2}{|c|}{ Percentages } \\
\hline Migrant status & 94.1 & 5.6 \\
\hline \multicolumn{3}{|l|}{ Host country: } \\
\hline Austria & 11.4 & 9.9 \\
\hline Belgium & 12.3 & 12.0 \\
\hline Denmark & 8.2 & 2.3 \\
\hline France & 12.6 & 14.2 \\
\hline Germany & 12.0 & 14.3 \\
\hline Greece & 4.8 & 0.9 \\
\hline Luxembourg & 2.3 & 12.5 \\
\hline Netherlands & 7.3 & 4.3 \\
\hline Portugal & 3.9 & 0.8 \\
\hline Spain & 7.4 & 2.6 \\
\hline Sweden & 11.8 & 12.1 \\
\hline Switzerland & 5.9 & 14.2 \\
\hline \multicolumn{3}{|c|}{ Pension scheme generosity: } \\
\hline Less protective & 42.6 & 45.7 \\
\hline More protective & 57.4 & 54.3 \\
\hline \multicolumn{3}{|l|}{ Age at interview: } \\
\hline $60-69$ & 44.2 & 48.1 \\
\hline $70-79$ & 38.4 & 38.0 \\
\hline $80+$ & 17.4 & 13.9 \\
\hline \multicolumn{3}{|l|}{ Sex: } \\
\hline Female & 47.3 & 47.4 \\
\hline Male & 52.7 & 52.6 \\
\hline \multicolumn{3}{|l|}{ Marital status: } \\
\hline Married/partnership & 69.3 & 67.4 \\
\hline Never married & 4.6 & 3.5 \\
\hline Divorced/separated & 7.5 & 12.1 \\
\hline Widowed & 18.6 & 17.0 \\
\hline \multicolumn{3}{|l|}{ Education (ISCED 1997): } \\
\hline No/low education & 47.7 & 43.8 \\
\hline Medium education & 32.6 & 30.1 \\
\hline High education & 19.7 & 26.1 \\
\hline
\end{tabular}


Table 1. (Continued)

\begin{tabular}{|ccc}
\hline & Non-migrants & Migrants \\
\hline Household income: & & \\
\hline Quartile 1 (lowest) & 24.2 & 21.2 \\
\hline Quartile 2 & 24.9 & 26.2 \\
\hline Quartile 3 & 25.6 & 22.3 \\
\hline Quartile 4 & 25.3 & 30.3 \\
\hline Average pension $(€):$ & & \\
\hline Mean & 41,894 & 37,193 \\
\hline Median & 16,313 & 15,870 \\
\hline
\end{tabular}

Note: ISCED: International Standard Classification of Education.

9 per cent lower. However, in the fully adjusted model (Model 3), including all control variables and interaction effects, the conditional effect of migration on pension was not statistically significant.

The significant interaction between migrant status and education in the fully adjusted model indicates the effect of higher education differed for migrants and non-migrants. Thus, while higher education levels generally increased pensions by around 29 per cent, at higher levels of education, migrants experience lower returns on their human capital compared to non-migrants. This result is highlighted by the education interaction plot (Figure 1).

The significant negative interaction between migrant status and pension generosity indicates that migrants in more generous systems (i.e. Austria, Belgium, Greece, Netherlands, Luxembourg, Spain and Sweden) have better pension outcomes; they are more protected against the impact of migration than those in lessgenerous systems (i.e. Denmark, Germany, Portugal, France and Switzerland). This is highlighted in the pension generosity interaction plot (Figure 2).

Of the control variables, all were significantly associated with pension outcomes, e.g. males received pensions 46 per cent higher than females. However, in Model 2, the association between migration and pension remained significant, indicating that migrants' pensions were lower than non-migrants' after accounting for age, sex, marital status and household income.

With the introduction of the interaction effects in Model 3, the conditional effect of migration in Table 3 represents the relationship between migration and pension when the moderators (pension generosity and education) have a value of zero (Fraizer et al., 2004). Therefore, the migration variable represents the effect of being a migrant with lower education, in a less-generous pension scheme; this likely explains the attenuation of statistical significance given that the moderating effects of both education and pension generosity interactions were shown to be significantly influential on pension outcomes.

In summary, this indicates that the combined effect of migration and pension generosity, and migration and education, are more influential in explaining differences in pension outcomes than the impact of migration by itself. 
Table 2. Descriptive statistics across migrant groups

\begin{tabular}{|c|c|c|c|c|}
\hline & $\begin{array}{l}\text { North } \\
\text { EEA }\end{array}$ & $\begin{array}{l}\text { South } \\
\text { EEA }\end{array}$ & $\begin{array}{l}\text { Low GDP } \\
\text { non-EEA }\end{array}$ & $\begin{array}{l}\text { High GDP } \\
\text { non-EEA }\end{array}$ \\
\hline \multirow[t]{2}{*}{$\mathrm{N}$} & 656 & 302 & 196 & 436 \\
\hline & \multicolumn{4}{|c|}{ Percentages } \\
\hline \multicolumn{5}{|l|}{ Host country: } \\
\hline Austria & 11.0 & 1.3 & 11.7 & 13.3 \\
\hline Belgium & 13.4 & 20.9 & 10.2 & 4.6 \\
\hline Denmark & 3.2 & 0.7 & 2.0 & 2.3 \\
\hline France & 3.5 & 20.9 & 18.4 & 23.9 \\
\hline Germany & 8.2 & 3.3 & 14.8 & 30.7 \\
\hline Greece & 0.2 & 0.7 & 1.5 & 1.8 \\
\hline Luxembourg & 14.5 & 28.1 & 5.6 & 1.8 \\
\hline Netherlands & 2.9 & 2.0 & 17.3 & 2.3 \\
\hline Portugal & 0.0 & 0.3 & 4.6 & 0.5 \\
\hline Spain & 3.5 & 0.7 & 2.0 & 2.8 \\
\hline Sweden & 20.3 & 3.3 & 6.1 & 8.5 \\
\hline Switzerland & 19.4 & 17.9 & 5.6 & 7.6 \\
\hline \multicolumn{5}{|l|}{$\begin{array}{l}\text { Pension scheme } \\
\text { generosity: }\end{array}$} \\
\hline Less protective & 34.3 & 43.0 & 45.4 & 64.9 \\
\hline More protective & 65.7 & 57.0 & 54.6 & 35.1 \\
\hline \multicolumn{5}{|l|}{ Migration: } \\
\hline Single migration & 81.6 & 88.4 & 81.6 & 85.1 \\
\hline Multiple migrations & 18.4 & 11.6 & 18.4 & 14.9 \\
\hline \multicolumn{5}{|l|}{ Age at migration: } \\
\hline $18-35$ & 73.3 & 90.4 & 70.9 & 66.3 \\
\hline $36-50$ & 16.3 & 7.6 & 17.3 & 16.7 \\
\hline $51-64$ & 10.4 & 2.0 & 11.7 & 17.0 \\
\hline \multicolumn{5}{|l|}{ Migration year: } \\
\hline 1945-1949 & 7.5 & 5.3 & 6.1 & 11.5 \\
\hline 1950-1959 & 18.1 & 24.5 & 16.8 & 9.9 \\
\hline 1960-1969 & 30.9 & 40.1 & 30.1 & 32.3 \\
\hline 1970-1979 & 22.1 & 27.2 & 26.5 & 17.9 \\
\hline 1980-1989 & 10.5 & 0.7 & 8.2 & 12.4 \\
\hline 1990-1999 & 5.9 & 1.3 & 7.7 & 14.7 \\
\hline $2000-2010$ & 4.9 & 1.0 & 4.6 & 1.4 \\
\hline
\end{tabular}


Table 2. (Continued)

\begin{tabular}{|c|c|c|c|c|}
\hline & $\begin{array}{l}\text { North } \\
\text { EEA }\end{array}$ & $\begin{array}{l}\text { South } \\
\text { EEA }\end{array}$ & $\begin{array}{l}\text { Low GDP } \\
\text { non-EEA }\end{array}$ & $\begin{array}{c}\text { High GDP } \\
\text { non-EEA }\end{array}$ \\
\hline \multicolumn{5}{|l|}{$\begin{array}{l}\text { Citizenship in host } \\
\text { country: }\end{array}$} \\
\hline No & 47.6 & 65.9 & 23.0 & 21.3 \\
\hline Yes & 52.4 & 34.1 & 77.0 & 78.7 \\
\hline \multicolumn{5}{|l|}{ Age at interview: } \\
\hline $60-69$ & 46.5 & 48.7 & 50.5 & 49.1 \\
\hline $70-79$ & 40.9 & 37.4 & 34.2 & 35.8 \\
\hline $80+$ & 12.7 & 13.9 & 15.3 & 15.1 \\
\hline \multicolumn{5}{|l|}{ Sex: } \\
\hline Female & 55.5 & 37.7 & 42.3 & 44.0 \\
\hline Male & 44.5 & 62.3 & 57.7 & 56.0 \\
\hline \multicolumn{5}{|l|}{ Marital status: } \\
\hline Married/partnership & 67.7 & 73.2 & 62.8 & 65.1 \\
\hline Never married & 3.8 & 2.0 & 6.1 & 2.8 \\
\hline Divorced/separated & 10.7 & 8.3 & 11.7 & 17.2 \\
\hline Widowed & 17.8 & 16.6 & 19.4 & 14.9 \\
\hline \multicolumn{5}{|l|}{ Education (ISCED 1997): } \\
\hline No/low education & 31.7 & 72.0 & 45.3 & 41.6 \\
\hline Medium education & 37.8 & 18.6 & 22.4 & 30.1 \\
\hline High education & 30.5 & 9.5 & 32.3 & 28.3 \\
\hline \multicolumn{5}{|l|}{ Household income: } \\
\hline Quartile 1 (lowest) & 13.7 & 21.2 & 26.0 & 30.3 \\
\hline Quartile 2 & 21.8 & 27.8 & 31.1 & 29.6 \\
\hline Quartile 3 & 24.8 & 17.5 & 21.4 & 22.2 \\
\hline Quartile 4 & 39.6 & 33.4 & 21.4 & 17.9 \\
\hline \multicolumn{5}{|l|}{ Average pension $(€)$ : } \\
\hline Mean & 49,628 & 31,442 & 32,183 & 25,578 \\
\hline Median & 21,012 & 16,859 & 13,384 & 11,155 \\
\hline
\end{tabular}

Notes: EEA: European Economic Area. GDP: Gross Domestic Product. ISCED: International Standard Classification of Education.

\section{EEA migrants versus non-migrants}

Comparing non-migrants with migrants only from the EEA, in the initial model after controlling for only country fixed effects, EEA migrants had significantly lower pensions than non-migrants, by 11 per cent. After accounting for the effect of education, and socio-demographic and socio-economic controls (Model 2), the 
Table 3. Linear regression: migrants' pension compared to non-migrants' pension

\begin{tabular}{|c|c|c|c|c|c|c|}
\hline & \multicolumn{2}{|c|}{ All migrants } & \multicolumn{2}{|c|}{ EEA migrants } & \multicolumn{2}{|c|}{ Non-EEA migrants } \\
\hline & $B(\mathrm{SE})$ & $\begin{array}{l}\% \text { pension } \\
\text { difference }^{1}\end{array}$ & $B(\mathrm{SE})$ & $\begin{array}{l}\text { \% pension } \\
\text { difference }^{1}\end{array}$ & $B(\mathrm{SE})$ & $\begin{array}{l}\% \text { pension } \\
\text { difference }^{1}\end{array}$ \\
\hline \multicolumn{7}{|l|}{ Model 1: } \\
\hline \multicolumn{7}{|c|}{ Migrant status (Ref. Non-migrants): } \\
\hline Migrant & $-0.12(0.03)$ & $-11.1^{\star \star \star}$ & & & & \\
\hline EEA migrant & & & $-0.11(0.04)$ & $-10.5^{\star \star}$ & & \\
\hline \multirow[t]{2}{*}{ Non-EEA migrant } & & & & & $-0.13(0.04)$ & $-12.3^{\star \star}$ \\
\hline & + Country FEs & & + Country FEs & & + Country FEs & \\
\hline Constant & $9.59^{\star \star \star}$ & & $9.58^{\star \star \star}$ & & $9.59^{\star \star *}$ & \\
\hline $\mathrm{N}$ & 18,387 & & 17,955 & & 17,774 & \\
\hline$R^{2}$ & 0.533 & & 0.534 & & 0.537 & \\
\hline \multicolumn{7}{|l|}{ Model 2: } \\
\hline \multicolumn{7}{|c|}{ Migrant status (Ref. Non-migrants): } \\
\hline Migrant & $-0.10(0.03)$ & $-9.0^{\star \star \star}$ & & & & \\
\hline EEA migrant & & & $-0.08(0.02)$ & $-8.01^{\star}$ & & \\
\hline Non-EEA migrant & & & & & $-0.12(0.04)$ & $-11.1^{\star \star}$ \\
\hline \multicolumn{7}{|c|}{ Education (Ref. Low/no): } \\
\hline Medium education & $0.08(0.02)$ & $8.7^{\star \star \star}$ & $0.09(0.02)$ & $9.1^{\star \star \star}$ & $0.09(0.02)$ & $9.0^{\star \star \star}$ \\
\hline High education & $0.24(0.02)$ & $26.9^{\star \star \star}$ & $0.25(0.02)$ & $27.9^{\star \star \star}$ & $0.25(0.02)$ & $28.1^{\star \star \star}$ \\
\hline Age at interview & $-0.00(0.00)$ & $-0.2^{\star}$ & $-0.00(0.00)$ & $-0.2^{*}$ & $-0.00(0.00)$ & $-0.2^{\star}$ \\
\hline
\end{tabular}


Sex (Ref. Female):

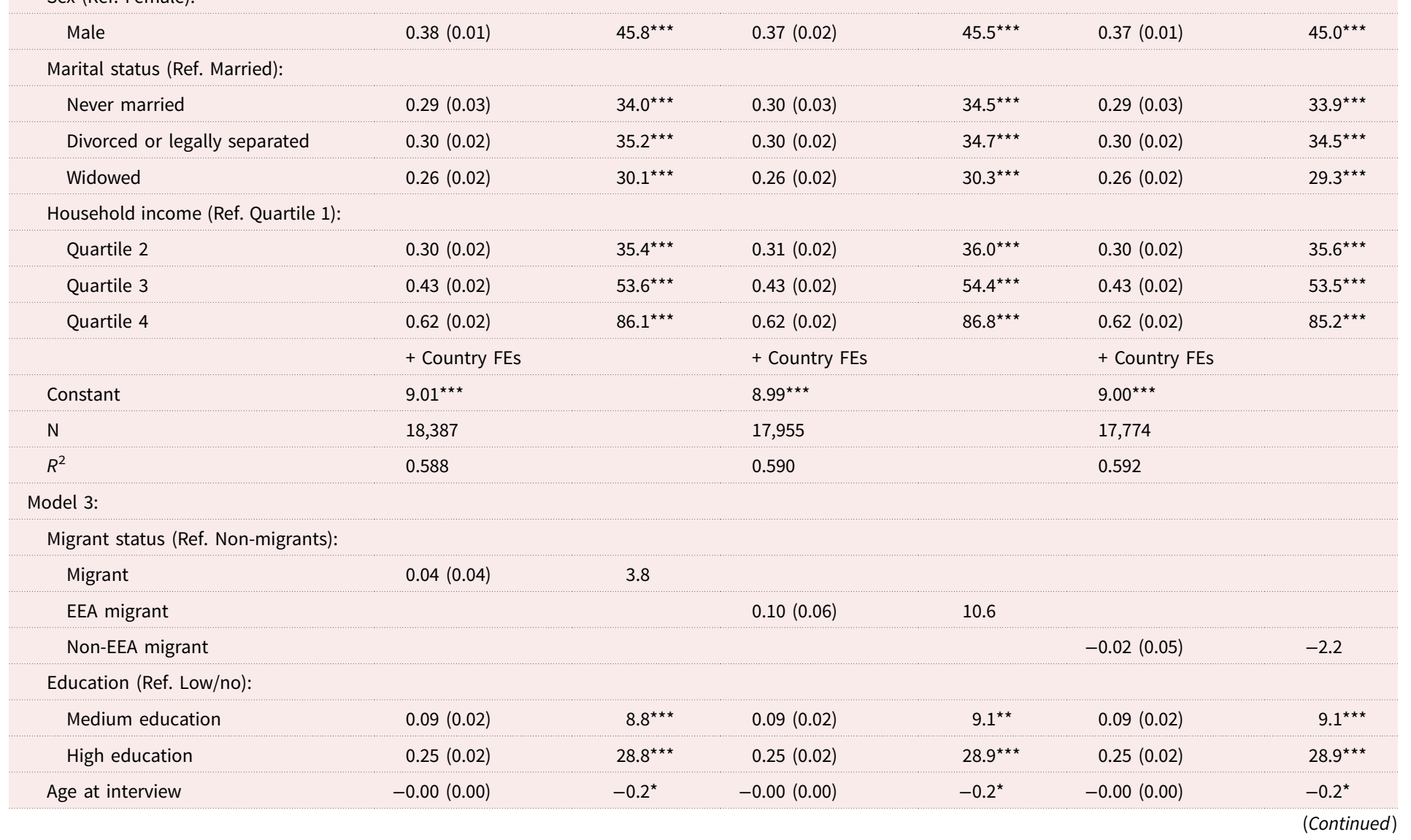


Table 3. (Continued)

\begin{tabular}{|c|c|c|c|c|c|c|}
\hline & \multicolumn{2}{|c|}{ All migrants } & \multicolumn{2}{|c|}{ EEA migrants } & \multicolumn{2}{|c|}{ Non-EEA migrants } \\
\hline & $B(\mathrm{SE})$ & $\begin{array}{l}\% \text { pension } \\
\text { difference }^{1}\end{array}$ & $B(\mathrm{SE})$ & $\begin{array}{l}\% \text { pension } \\
\text { difference }^{1}\end{array}$ & $B(\mathrm{SE})$ & $\begin{array}{l}\% \text { pension } \\
\text { difference }^{1}\end{array}$ \\
\hline \multicolumn{7}{|l|}{ Sex (Ref. Female): } \\
\hline Male & $0.38(0.01)$ & $45.7^{\star \star \star}$ & $0.37(0.01)$ & $45.4^{\star \star \star}$ & $0.37(0.01)$ & $45.0^{\star \star \star}$ \\
\hline \multicolumn{7}{|l|}{ Marital status (Ref. Married): } \\
\hline Never married & $0.29(0.03)$ & $33.9^{\star \star \star}$ & $0.30(0.03)$ & $34.5^{\star \star \star}$ & $0.29(0.03)$ & $33.8^{\star \star \star}$ \\
\hline Divorced or legally separated & $0.30(0.02)$ & $34.9^{\star \star \star}$ & $0.30(0.03)$ & $34.6^{\star \star \star}$ & $0.30(0.02)$ & $34.4^{\star \star \star}$ \\
\hline Widowed & $0.26(0.02)$ & $30.2^{\star \star \star}$ & $0.27(0.02)$ & $30.4^{\star \star \star}$ & $0.26(0.02)$ & $29.3^{\star \star \star}$ \\
\hline \multicolumn{7}{|l|}{ Household income (Ref. Quartile 1): } \\
\hline Quartile 2 & $0.30(0.02)$ & $35.4^{\star \star \star}$ & $0.31(0.02)$ & $36.0^{\star \star \star}$ & $0.30(0.02)$ & $35.6^{\star \star \star}$ \\
\hline Quartile 3 & $0.43(0.02)$ & $53.6^{\star \star \star}$ & $0.44(0.02)$ & $54.5^{\star \star \star}$ & $0.43(0.02)$ & $53.4^{\star \star \star}$ \\
\hline Quartile 4 & $0.62(0.02)$ & $86.0^{\star \star \star}$ & $0.63(0.02)$ & $86.9^{\star \star \star}$ & $0.62(0.02)$ & $85.0^{\star \star \star}$ \\
\hline \multicolumn{7}{|l|}{ Interactions: } \\
\hline Migrant $\times$ High education & $-0.18(0.06)$ & $-16.7^{\star \star}$ & $-0.18(0.08)$ & $-16.4^{\star}$ & $-0.18(0.09)$ & $-16.4^{\star}$ \\
\hline \multirow{2}{*}{$\begin{array}{l}\text { Migrant } \times \text { More protective } \\
\text { pension }\end{array}$} & $-0.17(0.05)$ & $-15.7^{\star \star}$ & $-0.24(0.07)$ & $-21.1^{\star \star}$ & $-0.12(0.08)$ & -11.5 \\
\hline & + Country FEs & & + Country FEs & & + Country FEs & \\
\hline Constant & $9.01^{\star \star \star}$ & & $9.00^{\star \star \star}$ & & $9.00^{\star \star \star}$ & \\
\hline $\mathrm{N}$ & 18,387 & & 17,955 & & 17,774 & \\
\hline$R^{2}$ & 0.589 & & 0.591 & & 0.593 & \\
\hline
\end{tabular}

Notes: Dependent variable: PensionLN (log transformation of public old age pension). 1. Calculated using (Exp $(B)-1) \times 100$. EEA: European Economic Area. SE: standard error. Ref.: reference group. FEs: fixed effects.

Significance levels: ${ }^{\star} p<0.05,{ }^{* \star} p<0.01,{ }^{\star * \star} p<0.001$. 


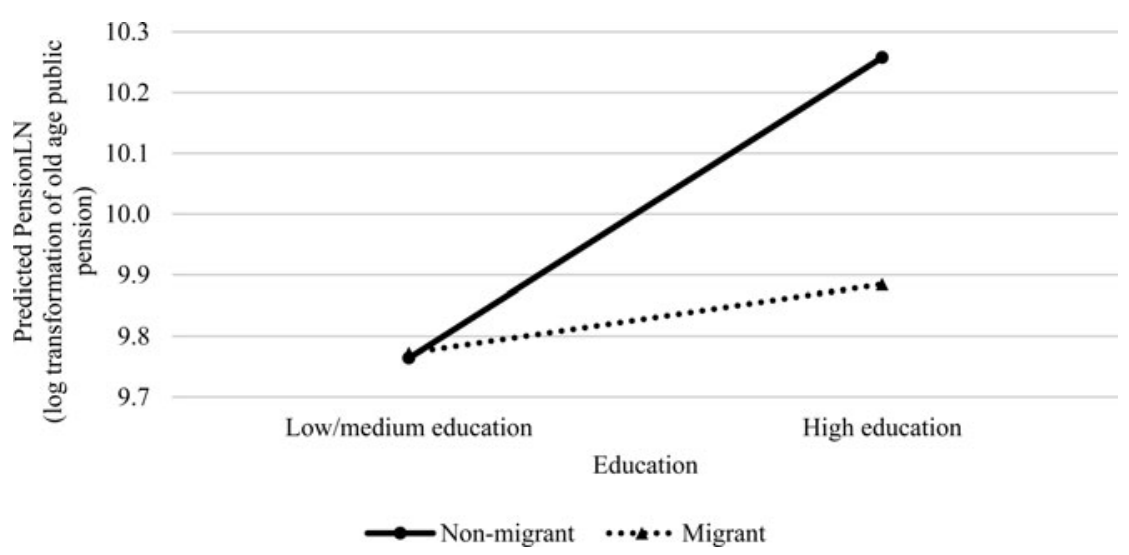

Figure 1. Interaction plot migration status (all migrants) by education.

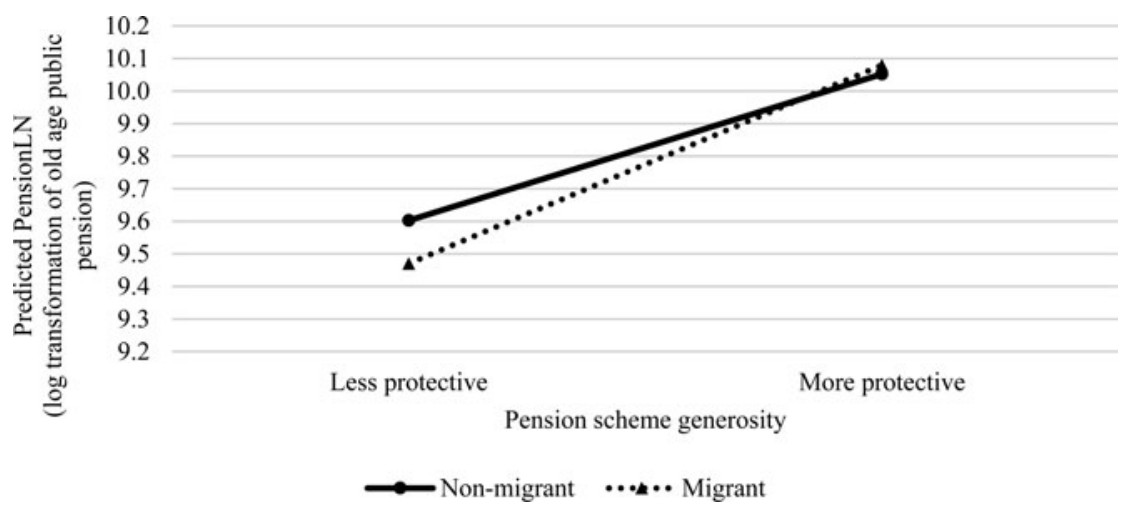

Figure 2. Interaction plot migration status (all migrants) by pension scheme generosity.

conditional effect of migration on pension remained significant; EEA migrants received pensions 8 per cent lower than non-migrants. However, the pension difference between EEA migrants and non-migrants was non-significant in the fully adjusted model (Table 3 ). Similar to the previous migrant versus non-migrant analysis, our analysis of the interaction effects suggests the difference in pension outcomes between EEA migrants and non-migrants is best explained by the unequal recognition of educational achievement between the two groups and the impact of pension systems, and not by the impact of migration itself.

The significant interaction between migration and education in the fully adjusted model (Model 3) indicates the effect of higher education differed for EEA migrants and non-migrants. Thus, while high education levels benefited all respondents in relation to pension outcome, by around 29 per cent, the interaction plot between migrant status and high education (Figure 3) highlights that highly educated EEA migrants received much lower average pensions than highly educated nonmigrants. This would suggest our hypothesis of relative advantages among EEA 


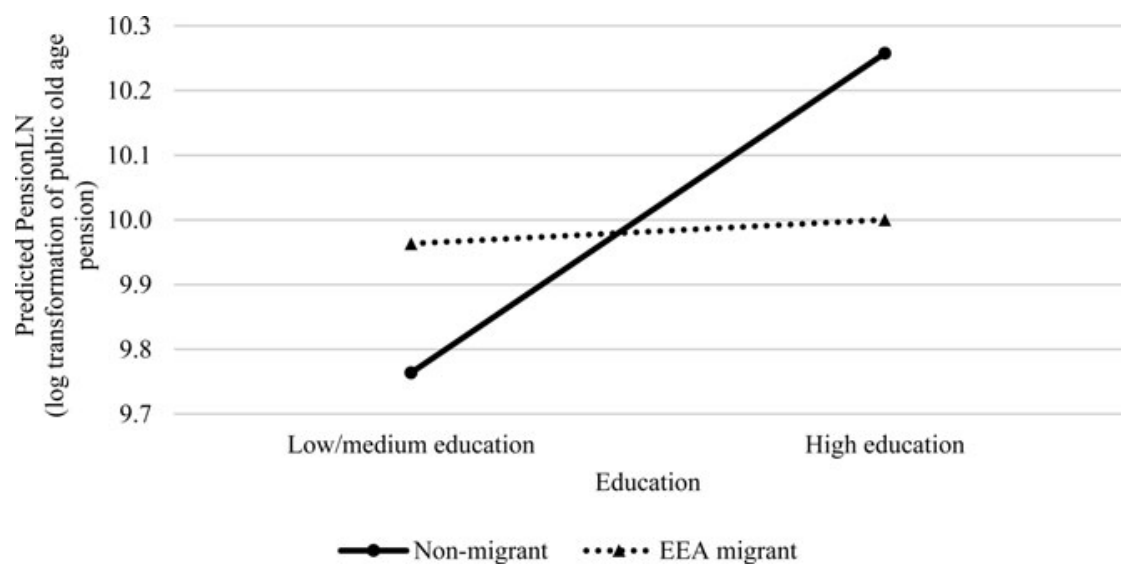

Figure 3. Interaction plot migration status (European Economic Area (EEA) migrants) by education.

migrants was erroneous: EEA migrants' human capital does not appear to be recognised adequately within host country labour markets.

The pension generosity interaction was also significant in the fully adjusted model (Model 3). The significant result from the regression analysis suggests that the impact of pension scheme generosity depends on whether the individual was an EEA migrant or a non-migrant, and that the latter benefits slightly more from a more generous system than the former. Figure 4 shows almost parallel increases in predicted pensions for both EEA migrants and non-migrants, but to interpret this correctly we have to consider that the difference within groups was greater for non-migrants than for EEA migrants and that EEA migrants' pensions were higher than non-migrants' pensions. Because of these two factors, nonmigrants will have experienced marginally greater benefit from the more protective schemes. In short, the magnitude of the difference in slopes is small, but statistically significant.

All of the included control variables were significantly associated with pension outcomes, e.g. respondents with the highest household incomes (quartile 4) reported pensions 87 per cent above those with the lowest household incomes (quartile 1). But as the association between migrant status and pension outcomes remained significant in Model 2, this suggested the control variables were not major factors in explaining the difference between EEA migrants' and nonmigrants' pensions.

As with the first regression including all migrants, the combined effects of being an EEA migrant and pension scheme generosity together with differences in respective returns from education best explain the pension discrepancies with non-migrants.

\section{Non-EEA migrants versus non-migrants}

Comparing non-EEA migrants' and non-migrants' pensions, significant differences were observed in Models 1 and 2. In Model 2, after accounting for education level, 


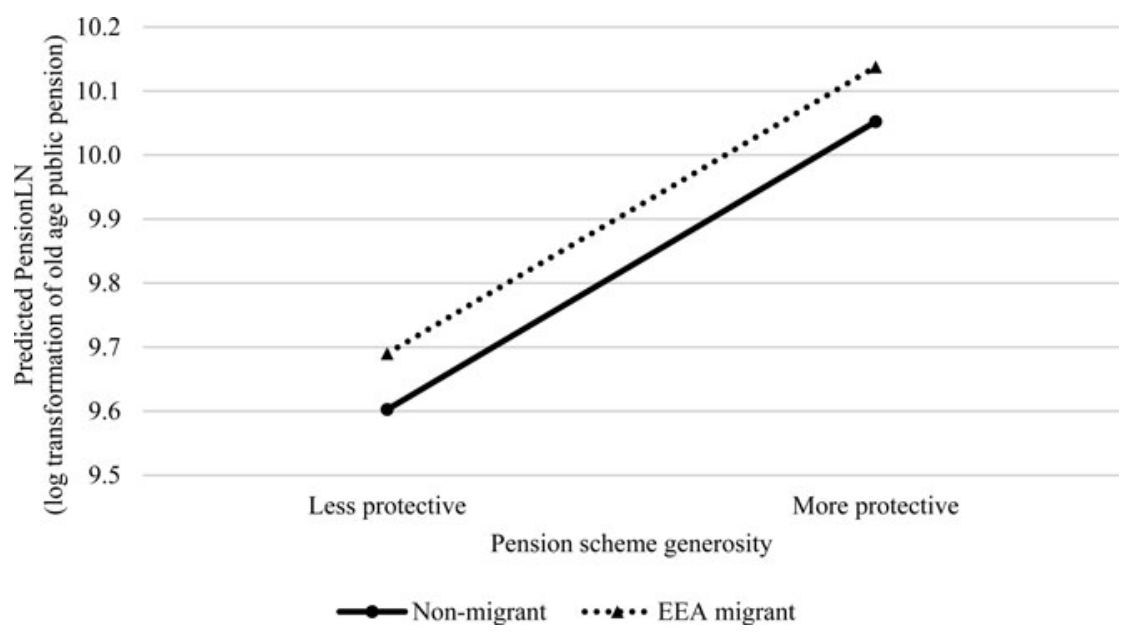

Figure 4. Interaction plot migration status (European Economic Area (EEA) migrants) by pension scheme generosity.

and controlling for socio-demographic and socio-economic factors, non-EEA migrants were disadvantaged, with pensions 11 per cent lower than those of nonmigrants (Table 3). Similar to the previous two analyses, the inclusion of interaction effects in Model 3 attenuated this significant association between migration and pension outcomes. However, unlike the analyses above, only the interaction between migration and education was significant.

The significant interaction between migration and education suggests that the impact of high education was not equal for non-migrants and non-EEA migrants. Overall, the conditional effect of high education increased pensions by 29 per cent compared to low education. However, while higher education levels slightly reduced the negative impact of migration on pension outcomes, as Figure 5 highlights, higher education was substantially more beneficial to the pensions of non-migrants than of non-EEA migrants.

In contrast, the interaction between migration and pension generosity was nonsignificant in the non-EEA migrant sample. Therefore, more protective pension schemes do not significantly reduce the disadvantage non-EEA migrants experience with regard to their pensions; discrepancies between non-EEA migrants' and nonmigrants' pensions were similar in countries with both more-, and less-, protective pension schemes.

All other included controls, age at interview, sex, marital status and household income, were significantly associated with pension outcome. All income groups had substantially higher pensions than the reference group (quartile 1). However, the association between migration and pension outcome was significant in Model 2 after accounting for household income and other control variables, but not in Model 3. Thus, the control variables were less influential in explaining the difference between non-EEA migrants' and non-migrants' pensions than the interaction effects. 


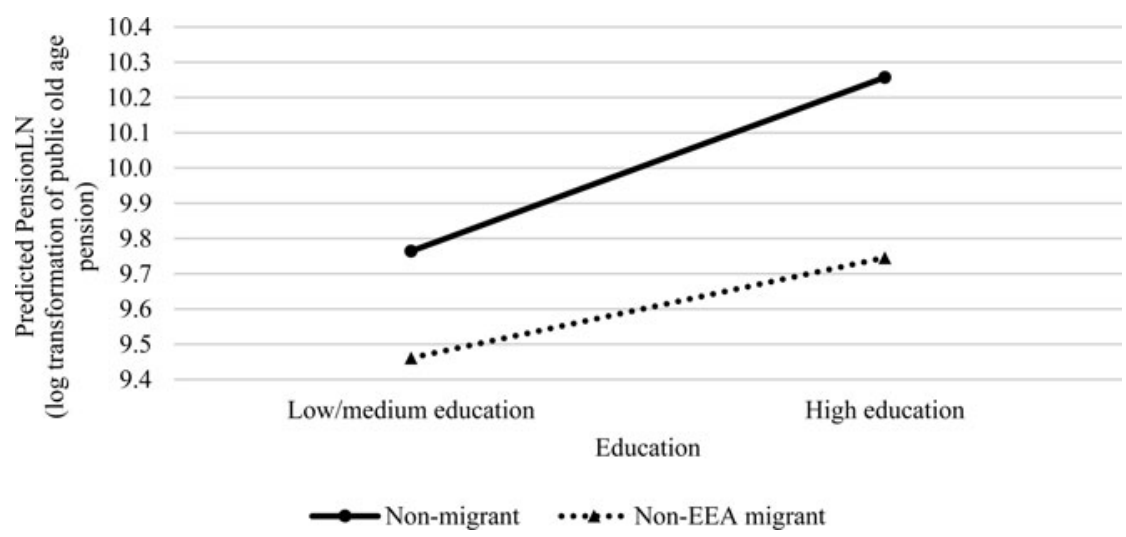

Figure 5. Interaction plot migration status (non-European Economic Area (EEA) migrants) by education.

\section{EEA migrants versus non-EEA migrants}

This analysis compares only the migrant sample, split into EEA and non-EEA groups. ${ }^{11}$ Initially, in Model 1, controlling only for country fixed effects, EEA migrants' pensions were 14 per cent higher than non-EEA migrants' pensions. After accounting for migrant-specific, socio-demographic and socio-economic control variables in Model 2, the magnitude of the pension discrepancy increased, EEA migrants' pensions were 15 per cent greater than non-EEA migrants' pensions. In the final model (Model 3), after controlling for the interaction between EEA migration and high education, EEA migrants' pensions remained significantly higher than non-EEA migrants' pensions by 16 per cent (Table 4).

Education was not a significant predictor of pension outcomes in this migrant-only analysis, nor was the interaction between EEA migration and education. This supports the finding from our EEA migrant and non-migrant analysis above that our original hypothesis that EEA migrants would experience a human capital advantage in relation to other migrants was erroneous. In fact, the returns to education are similar among EEA migrants and non-EEA migrants.

Of the migrant-specific predictors, only age at migration was significantly associated with pension outcomes in the fully adjusted model (Model 3). Those migrating aged 51-64 received pensions 28 per cent lower than those migrating between 18 and 35 years. This was expected given those migrating at older ages spent considerably less time in the host country labour market. Although most migrants within this sample migrated between the ages of 18 and 35, higher percentages of non-EEA migrants migrated later in life (Table 2) compared to EEA migrants.

The persistence of a significant difference between the pension outcomes of EEA and non-EEA migrants in the fully adjusted model suggests other factors, for which we had not controlled, exerted an important influence. However, as mentioned above, we could not include a pension generosity interaction in this analysis because it introduced collinearity between the interaction and the predictor and moderator variables. We were thus not able to investigate this factor in any more 
Table 4. Linear regression: European Economic Area (EEA) migrants' pension compared to non-EEA migrants' pension

$B(\mathrm{SE}) \quad \%$ pension difference ${ }^{1}$

Model 1:

Migrant status (Ref. Non-EEA migrants):

$\begin{array}{ll}\text { EEA migrant } & 0.13(0.06) \\ & + \text { Country FEs } \\ \text { Constant } & 9.48^{\star \star \star} \\ \mathrm{N} & 1,045 \\ R^{2} & 0.443\end{array}$

Model 2:

Migrant status (Ref. Non-EEA migrants):

EEA migrant

$0.14(0.06)$

$14.7^{*}$

Migrations (Ref. Single migration):

Multiple migrations

$0.02(0.07)$

Age at migration (Ref. 18-35):

36-50

51-64

$-0.32(0.16)$

$-27.6^{*}$

Year of migration (Ref. 1945-1959):

$\begin{array}{lcr}1960-1969 & -0.03(0.08) & -2.7 \\ 1970-1979 & -0.18(0.10) & -16.8 \\ 1980 \text { or later } & -0.03(0.16) & -2.8\end{array}$

Citizenship in host country (Ref. No):

\begin{tabular}{lcc} 
Yes & $0.04(0.06)$ & 4.0 \\
Age at interview & $-0.01(0.01)$ & -0.8 \\
Sex (Ref. Female): & & \\
Male & $0.52(0.06)$ & $68.9^{\star \star \star}$ \\
Marital status (Ref. Married): & & 31.9 \\
Never married & $0.28(0.15)$ & $48.1^{\star \star \star}$ \\
Divorced or legally separated & $0.39(0.09)$ & $41.2^{\star \star \star}$ \\
Widowed & $0.34(0.08)$ & -3.5 \\
Education (Ref. Low/no): & $-0.04(0.07)$ & 4.5 \\
Medium education & $0.04(0.07)$ & $18.1^{\star}$ \\
High education & & (Continued) \\
\hline Household income (Ref. Quartile 1): & $0.17(0.08)$ & \\
Quartile 2 &
\end{tabular}


Table 4. (Continued)

\begin{tabular}{|c|c|c|}
\hline & $B(\mathrm{SE})$ & $\%$ pension difference ${ }^{1}$ \\
\hline Quartile 3 & $0.31(0.09)$ & $36.5^{\star \star \star}$ \\
\hline \multirow[t]{2}{*}{ Quartile 4} & $0.56(0.10)$ & $75.1^{\star \star \star}$ \\
\hline & + Country $F$ & \\
\hline Constant & $9.47^{\star \star \star}$ & \\
\hline $\mathrm{N}$ & 1,045 & \\
\hline$R^{2}$ & 0.518 & \\
\hline \multicolumn{3}{|l|}{ Model 3: } \\
\hline \multicolumn{3}{|c|}{ Migrant status (Ref. Non-EEA migrants): } \\
\hline EEA migrant & $0.15(0.07)$ & $15.7^{\star}$ \\
\hline \multicolumn{3}{|l|}{ Migrations (Ref. Single migration): } \\
\hline Multiple migrations & $0.02(0.07)$ & 1.8 \\
\hline \multicolumn{3}{|l|}{ Age at migration (Ref. 18-35): } \\
\hline $36-50$ & $-0.07(0.11)$ & -7.1 \\
\hline $51-64$ & $-0.32(0.16)$ & $-27.6^{\star}$ \\
\hline \multicolumn{3}{|l|}{ Year of migration (Ref. 1945-1959): } \\
\hline 1960-1969 & $-0.03(0.08)$ & -2.6 \\
\hline $1970-1979$ & $-0.18(0.10)$ & -16.6 \\
\hline 1980 or later & $-0.03(0.16)$ & -2.7 \\
\hline \multicolumn{3}{|c|}{ Citizenship in host country (Ref. No): } \\
\hline Yes & $0.04(0.06)$ & 4.0 \\
\hline Age at interview & $-0.01(0.01)$ & -0.8 \\
\hline \multicolumn{3}{|l|}{ Sex (Ref. Female): } \\
\hline Male & $0.52(0.06)$ & $68.9^{\star \star \star}$ \\
\hline \multicolumn{3}{|l|}{ Marital status (Ref. Married): } \\
\hline Never married & $0.28(0.15)$ & 31.9 \\
\hline Divorced or legally separated & $0.39(0.09)$ & $48.1^{\star \star \star}$ \\
\hline Widowed & $0.35(0.08)$ & $41.3^{\star \star \star}$ \\
\hline \multicolumn{3}{|l|}{ Education (Ref. Low/no): } \\
\hline Medium education & $-0.04(0.07)$ & -3.5 \\
\hline High education & $0.06(0.10)$ & 6.2 \\
\hline \multicolumn{3}{|l|}{ Household income (Ref. Quartile 1): } \\
\hline Quartile 2 & $0.17(0.08)$ & $18.2^{\star}$ \\
\hline Quartile 3 & $0.31(0.09)$ & $36.6^{\star \star}$ \\
\hline Quartile 4 & $0.56(0.10)$ & $75.3^{\star \star \star}$ \\
\hline
\end{tabular}


Table 4. (Continued)

\begin{tabular}{llc}
\hline & \multicolumn{1}{c}{$B(\mathrm{SE})$} & \% pension difference ${ }^{1}$ \\
\hline Interaction: & & -3.0 \\
\hline EEA migrant $\times$ High education & $-0.03(0.12)$ & \\
& + Country FEs & \\
Constant & $9.46^{\star * *}$ \\
\hline $\mathrm{N}$ & 1,045 \\
$R^{2}$ & 0.518 \\
\hline
\end{tabular}

Notes: Dependent variable: PensionLN (log transformation of public old age pension). 1. Calculated using $(\operatorname{Exp}(B)-1) \times$ 100. SE: standard error. Ref.: reference group. FEs: fixed effects.

Significance levels: ${ }^{\star} p<0.05,{ }^{\star \star} p<0.01,{ }^{\star \star \star} p<0.001$.

detail, particularly whether the impact of host country pension systems varied by migrant type.

\section{North EEA migrants versus South EEA, low GDP non-EEA and high GDP non-EEA migrants}

Our final analysis divided the migrant sample into four groups by wealth of countries of origin. Surprisingly, the differences between groups were mostly non-significant. In the initial model the only significant result was that high GDP non-EEA migrants received 14 per cent lower pensions than North EEA migrants. This significant difference remained statistically significant in Model 2 after controlling for migrant-specific, socio-demographic and socio-economic control variables. However, in the fully adjusted model (Model 3), after the inclusion of an interaction effect between EEA migration and high education, there were no significant differences observed between the pensions of the migrant groups (Table 5).

As with the EEA versus non-EEA migrant analysis, the only migrant-specific variable associated with pension outcome was age at migration, those migrating between the ages of 51 and 64 received pensions 28 per cent lower than those migrating between 18 and 35 years. Again, neither the conditional effect of education nor the EEA migration and high education interaction were significant, suggesting that the pensions of migrants from different countries with varying economic wealth did not differ by education level. This implies that qualifications obtained by all migrant groups were similarly recognised in their host countries.

The lack of hypothesised significant differences, in any of the three models, between the average pensions of migrants from the rich North EEA and the South EEA and low GDP non-EEA groups is surprising. It is possible that the varying impact of host country pension systems on these groups helps explain this result but, again, the absence of a pension generosity interaction variable in this analysis meant we could not explore this factor fully. 
Table 5. Linear regression: North European Economic Area (EEA) migrants' pension compared to South EEA, low Gross Domestic Product (GDP) non-EEA and high GDP non-EEA migrants' pensions

\begin{tabular}{|c|c|c|}
\hline & $B(\mathrm{SE})$ & $\%$ pension difference ${ }^{1}$ \\
\hline \multicolumn{3}{|l|}{ Model 1: } \\
\hline \multicolumn{3}{|c|}{ Migrant status (Ref. North EEA migrants): } \\
\hline South EEA & $-0.01(0.08)$ & -1.1 \\
\hline Low GDP non-EEA & $-0.09(0.10)$ & -8.4 \\
\hline \multirow[t]{2}{*}{ High GDP non-EEA } & $-0.15(0.08)$ & $-13.9^{\star}$ \\
\hline & + Country FEs & \\
\hline Constant & $9.60^{\star \star \star}$ & \\
\hline $\mathrm{N}$ & 1,045 & \\
\hline$R^{2}$ & 0.443 & \\
\hline \multicolumn{3}{|l|}{ Model 2: } \\
\hline \multicolumn{3}{|c|}{ Migrant status (Ref. North EEA migrants): } \\
\hline South EEA & $-0.04(0.08)$ & -3.5 \\
\hline Low GDP non-EEA & $-0.14(0.09)$ & -12.9 \\
\hline High GDP non-EEA & $-0.15(0.07)$ & $-14.1^{\star}$ \\
\hline \multicolumn{3}{|l|}{ Migrations (Ref. Single migration): } \\
\hline Multiple migrations & $0.02(0.07)$ & 1.7 \\
\hline \multicolumn{3}{|l|}{ Age at migration (Ref. 18-35): } \\
\hline $36-50$ & $-0.07(0.10)$ & -7.2 \\
\hline $51-64$ & $-0.32(0.16)$ & $-27.4^{\star}$ \\
\hline \multicolumn{3}{|l|}{ Year of migration (Ref. 1945-1959): } \\
\hline 1960-1969 & $-0.03(0.08)$ & -2.7 \\
\hline 1970-1979 & $-0.18(0.10)$ & -16.9 \\
\hline 1980 or later & $-0.03(0.16)$ & -3.3 \\
\hline \multicolumn{3}{|c|}{ Citizenship in host country (Ref. No): } \\
\hline Yes & $0.04(0.06)$ & 3.9 \\
\hline Age at interview & $-0.01(0.01)$ & -0.8 \\
\hline \multicolumn{3}{|l|}{ Sex (Ref. Female): } \\
\hline Male & $0.53(0.06)$ & $69.3^{\star \star \star}$ \\
\hline \multicolumn{3}{|l|}{ Marital status (Ref. Married): } \\
\hline Never married & $0.27(0.15)$ & 31.4 \\
\hline Divorced or legally separated & $0.39(0.09)$ & $47.9^{\star \star \star}$ \\
\hline Widowed & $0.34(0.08)$ & $41.1^{\star \star \star}$ \\
\hline
\end{tabular}


Table 5. (Continued)

$B$ (SE) $\%$ pension difference ${ }^{1}$

Education (Ref. Low/no):

Medium education

High education

$-0.04(0.07)$

$-4.0$

$0.04(0.07)$

3.9

Household income (Ref. Quartile 1):

\begin{tabular}{lll} 
Quartile 2 & $0.17(0.08)$ & $18.1^{\star}$ \\
Quartile 3 & $0.31(0.09)$ & $36.2^{\star \star}$ \\
Quartile 4 & $0.56(0.10)$ & $74.8^{\star \star *}$ \\
\hline Constant & + Country FEs & \\
N & $9.63^{\star \star \star}$ & \\
$R^{2}$ & 1,045 & \\
\hline
\end{tabular}

Model 3:

Migrant status (Ref. North EEA migrants):

South EEA

Low GDP non-EEA

$-0.04(0.08) \quad-3.9$

High GDP non-EEA

$-0.15(0.10) \quad-14.1$

$\begin{array}{ll}-0.16(0.08) & -15.1\end{array}$

Migrations (Ref. Single migration):

Multiple migrations

$0.02(0.07)$

Age at migration (Ref. 18-35):

36-50

$-0.08(0.10)$

$-7.2$

51-64

$-0.32(0.16)$

$-27.5^{*}$

Year of migration (Ref. 1945-1959):

1960-1969

$-0.03(0.08)$

$-2.6$

1970-1979

$-0.18(0.10)$

$-16.6$

1980 or later

$-0.03(0.16)$

$-3.1$

Citizenship in host country (Ref. No):

$\begin{array}{lcc}\text { Yes } & 0.04(0.06) & 3.8 \\ \text { Age at interview } & -0.01(0.01) & -0.8 \\ \text { Sex (Ref. Female): } & & \\ \text { Male } & 0.53(0.06) & 69.5^{\star \star \star} \\ \text { Marital status (Ref. Married): } & & 31.3 \\ \text { Never married } & 0.27(0.15) & 48.0^{\star \star \star} \\ \text { Divorced or legally separated } & 0.39(0.09) & 41.2^{\star \star \star} \\ \text { Widowed } & 0.35(0.08) & \text { (Continued) }\end{array}$


Table 5. (Continued)

\begin{tabular}{|c|c|c|}
\hline & $B(\mathrm{SE})$ & $\%$ pension difference ${ }^{1}$ \\
\hline \multicolumn{3}{|l|}{ Education (Ref. Low/no): } \\
\hline Medium education & $-0.04(0.07)$ & -4.0 \\
\hline High education & $0.06(0.10)$ & 6.1 \\
\hline \multicolumn{3}{|l|}{ Household income (Ref. Quartile 1): } \\
\hline Quartile 2 & $0.17(0.08)$ & $18.2^{\star}$ \\
\hline Quartile 3 & $0.31(0.09)$ & $36.2^{\star \star}$ \\
\hline Quartile 4 & $0.56(0.10)$ & $75.1^{\star \star \star}$ \\
\hline \multicolumn{3}{|l|}{ Interaction: } \\
\hline \multirow[t]{2}{*}{ EEA migrant $\times$ High education } & $-0.04(0.13)$ & -3.9 \\
\hline & + Country $F$ & \\
\hline Constant & $9.63^{\star \star \star}$ & \\
\hline $\mathrm{N}$ & 1,045 & \\
\hline$R^{2}$ & 0.518 & \\
\hline
\end{tabular}

Notes: Dependent variable: PensionLN (log transformation of public old age pension). 1. Calculated using $(\operatorname{Exp}(B)-1) \times$ 100. SE: standard error. Ref.: reference group. FEs: fixed effects.

Significance levels: ${ }^{\star} p<0.05,{ }^{\star \star} p<0.01,{ }^{\star \star \star} p<0.001$.

\section{Discussion and conclusion}

This study compared the public pensions of migrants into and within the EEA who retired there with non-migrants. Based on the literature, we hypothesised that migrants' average pensions would be substantially lower than non-migrants' (e.g. Heisig et al., 2018). However, in the paper's main contribution, we also sought to identify the most important reasons why migrant pensions were below those of non-migrants, and whether these varied for different types of migrants. We explored the assumption that migrants were automatically disadvantaged by late entry into their host country due to the delay this causes in building entitlements. We expected pension outcomes would vary with country of origin; that intra-EEA migrants would demonstrate advantages over other migrants because their human capital would be better recognised by host countries and more easily expandable, fewer were likely to be refugees and because of easier portability of pension rights. Finally, we expected advantages for migrants from richer countries.

Firstly, we found some evidence migrants' average pensions were lower than non-migrants'. However, contrary to expectations, there was no systematic evidence this was caused by migrants' late labour market entry or employment discrimination at the periphery of the labour market. The significant migrant pension gap we found in our initial models, which controlled only for country fixed effects, remained significant in Model 2 when we controlled for socio-demographic characteristics, household income as a measure of socio-economic status. However, there was no longer significance in our fully adjusted models when interaction effects were added between migration and human capital (education) and pension 
generosity of the host country, respectively. The fact that our interaction effects accounted for initial migrant/non-migrant differences suggests that the influence of other factors, such as labour market discrimination at the periphery and late entry into the labour market, are limited at best.

The most significant factor disadvantaging migrants was failure of host country labour markets to provide the highly educated migrants with full rewards for their human capital, leading to lower pensions than similar non-migrants. We predicted this result for non-EEA migrants, given they find gaining an equivalent return on their human capital harder, for example, due to more limited language skills (Cebolla-Boado et al., 2015). More surprising was that this problem also affected EEA migrants. The reason for this cannot be explained with the available data, but it is plausible that the competition for the top jobs in national labour markets is fiercer than at the periphery and the most highly educated migrants are more likely to lose out against highly educated non-migrants than the lowest educated migrants against equivalent non-migrants. There could be an effect comparable to the 'glass ceiling' that highly paid women have long experienced in Europe, the USA and elsewhere, where social policies, pay bargaining procedures and, not least, discretionary promotions explain the widened pay gap at the top of the wage distribution. In comparison, a widened pay gap at the bottom ('sticky floor') is much rarer (Arulampalam et al., 2007; Konstantopolous and Constant, 2008). While we hypothesised advantages for EEA migrants compared to other migrant groups with regard to recognition of their human capital, this was not evident within the data. Interaction effects between EEA migrants and higher education indicated that pension differences between the EEA and non-EEA migrant groups were not dependent on education level. Thus, migrants as a whole were disadvantaged with regard to their human capital compared to non-migrants but this was not related to their country of origin.

The second factor disadvantaging migrants was that less-protective host country pension systems protected all migrants less well than comparable non-migrants. This confirms previous work, in that welfare state institutions play an important role and that some are much better for migrants (Heisig et al., 2018). However, the use, in our work, of a pension system variable based on the institutions that migrants would actually have experienced improves the robustness of this finding. Similar to previous work, we found no patterning by standard regime types (Morissens and Sainsbury, 2005; Heisig et al., 2018). Thus, both our moreprotective and less-protective groups of systems included a mix of welfare state types. For example, while there were two social democratic Beveridgean schemes in our more-protective group (Netherlands, Sweden), it also contained Austria, Belgium, Greece, Luxembourg and Spain. Generally, more-protective pension schemes were found to reduce the negative impact of migration on pension outcomes for all migrants. Overall non-EEA migrants were less well protected than non-migrants within the same pension systems, whereas EEA migrants tended to fare better; however, further research is required to compare EEA and non-EEA migrants directly.

Our results show fewer significant differences between migrants' and nonmigrants' pensions than previous work (Heisig et al., 2018; Bridgen and Meyer, 2020). This is likely because the focus in this study was on public pensions and, compared to Heisig et al. (2018), because our sample included a greater variety of migrants. 
Finally, variations between migrants' pensions based on the type of country from which they originated were generally less marked than we expected. Differences in pensions were observed between EEA and non-EEA migrants, but in our moredifferentiated analysis of variation between migrants based on the wealth of their countries of origin, we only found an initial significant difference between the average pensions of migrants from the richer North EEA countries and the richer (high GDP) non-EEA countries. In the migrant-only analyses (fourth and fifth regressions, respectively), the significant difference between EEA and non-EEA migrants' pensions remained significant, even after controlling for migrant-specific, sociodemographic and socio-economic control variables and with the inclusion of an interaction between EEA migration and high education; however, the difference between North EEA and high GDP non-EEA migrants' pensions attenuated in the final model with the inclusion of the EEA migration and high education interaction. The results emphasise an overall difference in EEA and non-EEA migrants' pensions which cannot be explained by our control variables, nor the country effects for which we control. Part of the explanation might be due to how different groups of migrants fared in the pension systems of the host countries but for technical reasons we were not able to explore this factor. We cannot, therefore, exclude the possibility that the significant differences we found between the average pensions of different groups of migrants were due to their varying experience of labour market segmentation.

\section{Limitations}

The use of fixed-effects models in this study may be limited by different national sample sizes. In countries where migrant sub-groups were small, within-group variation is limited, which could have contributed towards the insignificant results between EEA and non-EEA and migrants from richer and poorer countries. These differences were statistically significant in previous work (Bridgen and Meyer, 2020) and in preliminary, unpublished, analyses prior to controlling for country fixed effects.

Additionally, the limitations of secondary data should be acknowledged. For instance, the pension and household income values in SHARE are self-reported by the respondents, and this type of sensitive data can be subject to reporting errors due to social desirability (Moore et al., 2000; Angel et al., 2019). Within this paper, we include household income as a control for socio-economic status divided into quartiles, this therefore relies less on the exact reported value of income. Similarly, our results indicate pension differences reported as a percentage value rather than exact pension values received by each group.

\section{Policy recommendations}

We started this paper by stating that our research would be relevant for policy makers seeking to avoid a situation where the current generation of working migrants who stay in their host country post-retirement were poorer than comparable non-migrants. In this respect, our findings suggest policy makers should not assume migrants' late entry into host country labour markets inevitably 
disadvantages them in relation to their subsequent retirement income. They should also be less concerned than the segmentation literature suggests about the relative disadvantage of migrants in peripheral labour markets. Instead, most attention should be paid to relative obstacles to career progression of highly educated migrants. Policy makers should also consider the ways in which their pension systems, both standard and minimum, cater for migrants, particularly those from outside the EEA. Our results show migrants overall experienced similar protection to non-migrants only in more-generous schemes, whereas EEA migrants were better protected in both more- and less-generous schemes. Non-EEA migrants with weaker pension rights in their host countries were less protected regardless of the generosity of their host country system. More research is required on the specific mechanisms that protect migrants and why EEA migrants fared better than non-migrants even in less generous schemes. However, as shown by the experience of migrants overall, who lived and worked in more-protective systems, equal access and increasing replacement rates are important ways of removing the gap between migrants and non-migrants.

Supplementary material. The supplementary material for this article can be found at https://doi.org/10. 1017/S0144686X21001811

Data. This paper uses data from SHARE Waves 1, 2, 3, 4, 5, 6 and 7 (DOIs: 10.6103/SHARE.w1.710, 10.6103/SHARE.w2.710, 10.6103/SHARE.w3.710, 10.6103/SHARE.w4.710, 10.6103/SHARE.w5.710, 10.6103/SHARE.w6.710, 10.6103/SHARE.w7.710), see Börsch-Supan et al. (2013) for methodological details. This paper also uses data from the generated Job Episodes Panel (DOI: 10.6103/SHARE.jep.710), see Brugiavini et al. (2019) for methodological details. The Job Episodes Panel release 7.1.0 is based on SHARE Waves 3 and 7 (DOIs: 10.6103/SHARE.w3.710, 10.6103/SHARE.w7.710).

Acknowledgments. The authors would like to thank Kati Kuitto, Katja Möhring, two anonymous reviewers and the editor of Ageing \& Society for their constructive comments.

Author contributions. All authors contributed to the conceptualisation, data analysis and writing.

Financial support. This work was supported by the ESRC Centre for Population Change (grant number ES/K007394/1).

Conflict of interest. The authors declare no conflicts of interest.

Ethical standards. Not applicable.

\section{Notes}

1 We only include EEA members from the 1990s, when migrants would have accrued pension rights. We exclude all countries that joined after 2000.

2 In fact, economic theories expect migrants to return before retirement. According to 'neo-classical' models, migrants will return if the wage gap narrows in favour of the country of origin (Sjaastad, 1962). According to the 'new economics' of migration, migrants save towards a target and return home once this is, or can no longer be, reached.

3 Switzerland (non-EEA) is included as a founding member of the European Free Trade Area, closely linked to the EEA/EU.

4 This was because we decided any pension income reported by participants before this age was highly unlikely to be a public pension. 
5 We wanted to include only migrants who migrated up to age 55, with more time working in their host country; but this reduced the size of the migrant sample substantially, which in turn we considered would restrict our analyses, thus we included all migrants migrating between the ages of 18 and 64 (working age). 6 SHARE grouped monthly and four-weekly time periods together without information about the precise time period of each. We would have multiplied the former by 12 and the latter by 13 but this was not possible so we multiplied all amounts by 12 . The scale of the consequent slight underestimation for some individuals' pension is likely to be marginal.

7 Data for Portugal were only available from the CWED dataset.

8 It is not specified in the data where migrants received their education, but all of them migrated as adults, therefore we assume that most were educated in their host countries.

9 Specifically, the sign of the interaction does not necessarily align with the prediction. The most important feature in interpreting coefficients for interaction effects is the significance value. This is why visual representations (such as our interaction plots) are an important interpretive aid to accompany interaction effects (Hayes, 2017: 244). In Table 3 this is true: the interaction effect for migrant $\times$ high education and migrant $\times$ more protective pension is significant and negative in both cases, but in the former it means migrant pension return with increasing education are lower than non-migrant's while in the latter it means that migrants' pension return is more favourable than non-migrants' in more protective systems.

10 Non-EEA countries were divided using Madison Project data. GDP per capita data were obtained for each country for around 1950 (1948-1952) and another around 1972 (1972-1973). The mean was then calculated between the two values. The latter date was used when only this was available.

11 The migrant-only regressions were based on a complete case analyses: 545 migrants from the initial sample had missing data on one or more of the variables included in these regressions. This explains why the migrant sample size is reduced to 1,045 for these analyses.

\section{References}

Ackers L and Dwyer P (2004) Fixed laws, fluid lives: the citizenship status of post-retirement migrants in the European Union. Ageing \& Society 24, 451-475.

Angel S, Disslbacher F and Humer S (2019) What did you really earn last year?: explaining measurement error in survey income data. Journal of the Royal Statistical Society: Series A (Statistics in Society) 182, 1411-1437.

Arulampalam W, Booth AL and Bryan ML (2007) Is there a glass ceiling over Europe? Exploring the gender pay gap across the wage distribution. ILR Review 60, 163-186.

Becker GS (1957) The Economics of Discrimination, 2nd Edn. Chicago, IL: University of Chicago Press.

Benoit K (2011) Linear regression models with logarithmic transformations. London School of Economics, London 22, 23-36. Available at https://links.sharezomics.com/assets/uploads/files/1600247928973from_slack_logmodels2.pdf. Accessed February 2020.

Bergmann M, Kneip T, De Luca G and Scherpenzeel A (2019) Survey participation in the Survey of Health, Ageing and Retirement in Europe (SHARE), Waves 1-7. SHARE-ERIC, Munich, SHARE Working Paper Series 41-2019.

Bolzman C (2012) Democratization of ageing: also a reality for elderly immigrants? European Journal of Social Work 15, 97-113.

Bolzman C, Poncioni-derigo R, Vial M and Fibbi R (2004) Older labour migrants' well being in Europe: the case of Switzerland. Ageing \& Society 24, 411-429.

Börsch-Supan A (2020a) Survey of Health, Ageing and Retirement in Europe (SHARE) Wave 1. Release version 7.1.0. SHARE-ERIC (Dataset). Available at https:/doi.org/10.6103/SHARE.w1.710.

Börsch-Supan A (2020b) Survey of Health, Ageing and Retirement in Europe (SHARE) Wave 2. Release version 7.1.0. SHARE-ERIC (Dataset). Available at https://doi.org/10.6103/SHARE.w2.710.

Börsch-Supan A (2020c) Survey of Health, Ageing and Retirement in Europe (SHARE) Wave 3 SHARELIFE. Release version 7.1.0. SHARE-ERIC (Dataset). Available at https://doi.org/10.6103/ SHARE.w3.710.

Börsch-Supan A (2020d) Survey of Health, Ageing and Retirement in Europe (SHARE) Wave 4. Release version 7.1.0. SHARE-ERIC (Dataset). Available at https://doi.org/10.6103/SHARE.w4.710. 
Börsch-Supan A (2020e) Survey of Health, Ageing and Retirement in Europe (SHARE) Wave 5. Release version 7.1.0. SHARE-ERIC (Dataset). Available at https://doi.org/10.6103/SHARE.w5.710.

Börsch-Supan A (2020f) Survey of Health, Ageing and Retirement in Europe (SHARE) Wave 6. Release version 7.1.0. SHARE-ERIC (Dataset). Available at https://doi.org/10.6103/SHARE.w6.710.

Börsch-Supan A (2020g) Survey of Health, Ageing and Retirement in Europe (SHARE) Wave 7. Release version 7.1.0. SHARE-ERIC (Dataset). Available at https://doi.org/10.6103/SHARE.w7.710.

Börsch-Supan A, Brandt M, Hunkler C, Kneip T, Korbmacher J, Malter F, Schaan B, Stuck S and Zuber S (2013) Data resource profile: the Survey of Health, Ageing and Retirement in Europe (SHARE). International Journal of Epidemiology 42, 992-1001.

Bridgen P and Meyer T (2019) Diminished citizenship: how retirement in the host country affects the financial status of intra-EU migrants. Ageing \& Society 39, 465-487.

Bridgen P and Meyer T (2020) The poverty risks of migrants who retire in their host country. Evidence from the first post-war wave of migration into Europe. In Evandrou M, Falkingham J and Vlachantoni A (eds), Handbook of Demographic Change and the Lifecourse. Cheltenham, UK: Edward Elgar, pp. 274-296.

Brugiavini A, Orso CE, Genie MG, Naci R and Pasini G (2019) Combining the retrospective interviews of wave 3 and wave 7: the third release of the SHARE Job Episodes Panel. SHARE-ERIC, Munich, SHARE Working Paper Series 36-2019.

Brugiavini A, Orso CE, Genie MG, Naci R and Pasini G (2020) SHARE Job Episodes Panel. Release version 7.1.0. SHARE-ERIC (Dataset). Available at https://doi.org/10.6103/SHARE.jep.710.

Castles S and Kosack G (1973) Immigrant Workers and Class Structure in Western Europe. London: Oxford University Press for the Institute of Race Relations.

Castles S, Booth H and Wallace T (eds) (1984) Here for Good: Western Europe's New Ethnic Minorities. London: Pluto Press.

Cebolla-Boado H, Miyar-Busto $\mathbf{M}$ and Munoz-Comet J (2015) Is the Spanish recession increasing inequality? Male migrant-non-migrant differences in educational returns against unemployment. Journal of Ethnic and Migration Studies 41, 710-728.

Chiswick B (1979) The economic progress of immigrants: some apparently universal patterns. In Fellner W (ed.), Contemporary Economic Problems. Washington, DC: American Enterprise Institute, pp. 359-399.

Comet JM (2014) Qué trabajos ocupan quienes abandonan el desempleo? Diferencias entre españoles y extranjeros en un contexto de cambio económico [Into which jobs do the unemployed move? Differences between Spaniards and foreigners in a changing economy]. Revista Internacional de Sociologia 72, 353-376.

Constant A and Massey DS (2005) Labor market segmentation and the earnings of German guestworkers. Population Research and Policy Review 24, 489-512.

Cortes KE (2004) Are refugees different from economic immigrants? Some empirical evidence on the heterogeneity of immigrant groups in the United States. Review of Economics and Statistics 86, 465-480.

de Coulon A and Wolff F-C (2005) Immigrants at retirement: stay/return or 'va-et-vient'? Centre for Economic Performance, LSE, London, CEP Discussion Paper 691.

Dingemans E and Möhring K (2019) A life course perspective on working after retirement: what role does the work history play? Advances in Life Course Research 39, 23-33.

Dustmann C (1996) Return migration: the European experience. Economic Policy 22, 215-250.

Dustmann C and Fabbri F (2003) Language proficiency and the labor market performance of immigrants in the United Kingdom. The Economic Journal 113, 695-717.

Dustmann C and Kirchkamp O (2000) The optimal migration duration and economic activities after return migration. Journal of Development Economics 67, 351-372.

Ebbinghaus B (2021) Inequalities and poverty risks in old age across Europe: The double-edged income effect of pension systems. Social Policy and Administration 55, 440-455. https://doi.org/10.1111/spol. 12683.

Edin P, LaLonde RJ and Åslund O (2000) Emigration of immigrants and measures of immigrant assimilation: evidence from Sweden. Swedish Economic Policy Review 7, 163-204.

Eurostat (2021) Population on 1 January by age group, sex and country of birth (Dataset). Available at https://ec.europa.eu/eurostat/web/products-datasets/-/MIGR_POP3CTB.

Field A (2013) Discovering Statistics Using IBM SPSS Statistics, 4th Edn. London: Sage.

Fraizer PA, Tix AP and Barron KE (2004) Testing moderator and mediator effects in counselling psychology research. Journal of Counselling Psychology 51, 115-134. 
Ginn J (2003) Gender, Pensions and the Lifecourse: How Pensions Need to Adapt to Changing Family Forms. Bristol, UK: Policy Press.

Green AE, Owen D, Jones P, Owen C, Francis J and Proud R (2008) Migrant Workers in the South East Regional Economy. Final Report. Warwick Institute for Employment Research and BMG Research. Available at https://www.researchgate.net/publication/265539730_Migrant_Workers_in_the_South_East_ Regional_Economy.

Hall $\mathbf{M}$ and Farkas $\mathbf{G}$ (2008) Does human capital raise earnings for immigrants in the low-skill labor market? Demography 45, 619-639.

Hayes AF (2017) Introduction to Mediation, Moderation, and Conditional Process Analysis: A Regression-based Approach. London: Guilford Press.

Heisig JP, Lancee B and Radl J (2018) Ethnic inequality in retirement income: a comparative analysis of immigrant-native gaps in Western Europe. Ageing \& Society 38, 1963-1994.

Hochfellner D and Burkert C (2013) Berufliche Aktivität im Ruhestand. Fortsetzung der Erwerbsbiographie oder notwendiger Zuverdienst? Zeitschrift für Gerontologie und Geriatrie 46, 242-250.

Hyde M and Dingemans E (2017) Hidden in plain sight? Does stricter employment protection legislation lead to an increased risk of hidden unemployment later in life? Work, Aging and Retirement 3, 231-242.

Klinthäll M (2006) Retirement return migration from Sweden. International Migration 44, 153-178.

Konstantopoulos S and Constant A (2008) The gender gap reloaded: are school characteristics linked to labor market performance? Social Science Research 37, 374-385.

Korpi W and Palme J (2008) The Social Citizenship Indicator Program (SCIP). Stockholm: SOFI, Stockholm University.

Lancee B and Bol T (2017) The transferability of skills and degrees: why the place of education affects immigrant earnings. Social Forces 96, 691-716.

Luxembourg Income Study (LIS) (2019) METIS by LIS (Dataset). Available at http://www.lisdatacenter. org/frontend\#/database/1/selection.

Meyer T (2017) How European pension promises changed in austere times: 2002-15. In Kennett P and Lendvai-Bainton N (eds), Handbook of European Social Policy. Cheltenham, UK: Edward Elgar Publishing, pp. 329-350.

Meyer T, Bridgen P and Andow C (2012) Free movement? The impact of legislation, benefit generosity and wages on the pensions of European migrants. Population, Place and Space 19, 714-726.

Mika T and Tucci I (2006) Alterseinkommen bei Zuwanderern. Gesetzliche Rente und Haushaltseinkommen bei Aussiedlern und Zuwanderern aus der Türkei und dem ehemaligen Jugoslawien im Vergleich zur deutschen Bevölkerung [Old age income among immigrants. Public pension and household income of 'Aussiedler' and immigrants from Turkey and former Yugoslavia in comparison to the German population]. Deutsche Rentenversicherung 61, 456-483.

Möhring K (2012) The fixed effects approach as alternative to multilevel models for cross-national analyses. Paper presented at the 10th ESPAnet Conference, Edinburgh. Available at https://osf.io/ preprints/socarxiv/3xw7v/.

Möhring K (2015) Employment histories and pension incomes in Europe: a multilevel analysis of the role of institutional factors. European Societies 17, 3-26.

Möhring K (2018) Is there a motherhood penalty in retirement income in Europe? The role of lifecourse and institutional characteristics. Ageing \& Society 38, 2560-2589.

Moore JC, Stinson LL and Welniak EJ (2000) Income measurement error in surveys: a review. Journal of Official Statistics 16, 331-362.

Morissens A and Sainsbury D (2005) Migrants' social rights, ethnicity and welfare regimes. Journal of Social Policy 34, 637-660.

Organisation for Economic Co-operation and Development (OECD) (2005-2019) OECD Pensions at a Glance. Available at https://www.oecd-ilibrary.org/finance-and-investment/oecd-pensions-at-a-glance_19991363.

Organisation for Economic Co-operation and Development (OECD) (2018) Inflation (CPI). Available at https://data.oecd.org/price/inflation-cpi.htm.

Piore MJ (1979) Birds of Passage: Migrant Labor in Industrial Societies. New York, NY: Cambridge University Press.

Poulain M and Perrin N (2002) The demographic characteristics of immigrant populations in Belgium. In Haug W, Compton P and Courbage Y (eds), The Demographic Characteristics of Immigrant Populations. Strasbourg, France: Council of Europe Publishing, pp. 57-129. 
Powers MG and Seltzer W (1998) Occupational status and mobility among undocumented immigrants by gender. International Migration Review 32, 21-55.

Ruiz I and Vargas-Silva C (2017) Are refugees' labour market outcomes different from those of other migrants? Evidence from the United Kingdom in the 2005-2007 period. Population, Space and Place 23, $1-15$.

Scruggs L, Detlef J and Kuitto K (2017a) Comparative Welfare Entitlements Dataset 2. Version 2017-09 (Dataset). Storrs, CT and Greifswald, Germany: University of Connecticut and University of Greifswald.

Scruggs L, Detlef J and Kuitto K (2017b) Comparative Welfare Entitlements Dataset 2 Codebook. Version 2017-09. Storrs, CT and Greifswald, Germany: University of Connecticut and University of Greifswald. Sjaastad LA (1962) The costs and returns of human migration. Journal of Political Economy 70, 80-93.

Stark O (1991) The Migration of Labor. Cambridge, MA: Blackwell.

Survey of Health, Ageing and Retirement in Europe (SHARE) (2017) Wave 7 Questionnaire. Available at http://www.share-project.org/fileadmin/pdf_questionnaire_wave_7/w7_7.4.3.001_paper_questionnaire_ main.pdf.

Taylor JE (1999) The new economics of labour migration and the role of remittances in the migration process. International Migration 37, 63-88.

Vlachantoni A, Feng F, Evandrou M and Falkingham J (2017) Ethnic elders and pension protection in the United Kingdom. Ageing \& Society 37, 1025-1039.

Warnes AW (2006) Migration, older people and social policy. In Clarke K, Maltby T and Kennett P (eds), Social Policy Review 19. Analysis and Debate in Social Policy, 2007. Bristol, UK: Policy Press, pp. 293-216.

Zwysen W (2019) Different patterns of labor market integration by migration motivation in Europe: the role of host country human capital. International Migration Review 53, 58-89.

Cite this article: Bridgen P, Meyer T, Davison L (2022). It's not late entry: human capital, welfare states and the pension penalty experienced by post-war migrants who retired in the European Economic Area. Ageing \& Society 1-33. https://doi.org/10.1017/S0144686X21001811 